https://doi.org/10.32689/2618-0065-2020-3(5)-22-33

Воротін Валерій Євгенович, доктор наук з державного управління, професор, завідувач відділу комплексних проблем державотворення Інституту законодавства Верховної Ради України, м. Київ, пров. Несторівський, 4, 04053, Україна, +380502327110, e-mail: vevorotin@gmail.com, https://orcid.org/0000-0002-4545-612X

Шевченко Алла Володимирівна, аспірант Інституту Законодавства Верховної Ради України, м. Київ, пров. Несторівський, 4, 04053, Україна, +380507878909, e-mail: allanika@ukr.net, https://orcid.org/0000-0003-3062-8715

\title{
ПІДТРИМКА МІЖДЕРЖАВНОГО РЕГІОНАЛЬНОГО СПІВРОБІТНИЦТВА: ІНСТИТУЦІЙНІ ПЕРСПЕКТИВИ РОЗВИТКУ СВРОРЕГІОНІВ
}

Анотація. У науковій літературі поняття єврорегіон має різні тлумачення, зокрема більшість науковців характеризують єврорегіон як форму міждержавного регіонального (транскордонного) співробітництва між територіальними громадами або місцевими органами влади прикордонних регіонів двох або більше держав, що мають спільний кордон, яке спрямоване на координацію їх взаємних зусиль і здійснення узгоджених заходів у різних сферах життєдіяльності у відповідності до національних законодавств і норм міжнародного права для вирішення спільних проблем і в інтересах людей, що населяють його територію по обидві боки державного кордону. Основними характеристиками єврорегіону, які застосовуються в науковій літературі, $\epsilon$ наступні: географічна - єврорегіон $є$ територією, яка має конкретне географічне положення; політична - частини цієї території знаходяться під юрисдикцією суверенних держав, які мають спільний кордон.

Доведено, що єврорегіони утворюють прикордонні регіони держав, що мають спільний кордон; функціональна - єврорегіон $\epsilon$ формою міждержавного регіонального (транскордонного) співробітництва. Основні завдання, які за аналізом наукових джерел, слід сформулювати для діяльності єврорегіонів, наступні: обмін досвідом та інформацією; вирівнювання та постійне покращення життєвих умов; підтримка регіонального розвитку; розвиток економіки, торгівлі та туризму; охорона й покращення стану навколишнього середовища; співробітництво в запобіганні та подоланні стихійних лих і катастроф; співпраця в області гуманітарної та соціальної діяльності, у сфері освіти, спорту і охорони здоров'я; культурний обмін і турбота про культурне надбання.

Обгрунтовано, що на відміну від утворення та функціонування єврорегіональних структур в Європейському співтоваристві, де ініціатива утворення таких структурних одиниць в основному, належить місцевим 
громадам, усі єврорегіони за участю адміністративно-територіальних одиниць України були ініційовані структурами державного управління. Це має як позитивні моменти, оскільки з одного боку, це свідчить про те, що на рівні вищих органів влади присутнє усвідомлення в необхідності участі в сучасних інтеграційних проектах, налагодженні добросусідських відносин між сусідніми державами. 3 іншого боку, в умовах децентралізації необхідним стає підвищення самостійності місцевих властей, активна місцева політика в сфері міждержавного регіонального співробітництва.

Визначено, що на сьогодні єврорегіон є основним інструментом для забезпечення співробітництва на рівні регіонів та територіальних громад, виступаючи як транскордонна регіональна асоціація прикордонних адміністративних територій 3 метою координації міждержавного регіонального співробітництва.

Ключові слова. Державне управління, регіональне управління, єврорегіон, міждержавне регіональне співробітництво.

Vorotin Valerii Yevhenovych, Doctor of Science in Public Administration,

Professor, Head of the Department of Complex Problems of State-Building of the Institute of Legislation of the Verkhovna Rada of Ukraine, Kyiv, 4, Nestorivskyi provulok, 04053, Ukraine, +380502327110, e-mail: vevorotin@gmail.com, https://orcid.org/0000-0002-4545-612X

Shevchenko Alla Volodymyrivna, Staff of the Verkhovna Rada, Assistant Consultant to the People's Deputy of Ukraine, Postgraduate Student of the Institute of Legislation of the Verkhovna Rada of Ukraine, Kyiv, 4, Nestorivskyi provulok, 04053, Ukraine, +380507878909, e-mail: allanika@ukr.net, https://orcid.org/00000003-3062-8715

\section{Supporting interstate regional cooperation: institutional prospects for the development of euroregions}

Abstract. In the scientific literature, the concept of Euroregion has different interpretations, in particular, most scholars characterize the Euroregion as a form of interstate regional (cross-border) cooperation between territorial communities or local authorities of border regions of two or more states that have a common border. coordinated measures in various spheres of life in accordance with national laws and norms of international law to address common problems and in the interests of the people inhabiting its territory on both sides of the state border. The main characteristics of the Euroregion, which are used in the scientific literature, are the following: geographical - the Euroregion is a territory that has a specific geographical location; political - parts of this territory are under the jurisdiction of sovereign states that have a common border.

It is proved that Euroregions form border regions of states that have a common border; functional - the Euroregion is a form of interstate regional (crossborder) cooperation. The main tasks, which according to the analysis of scientific 
sources, should be formulated for the activities of Euroregions, are the following: exchange of experience and information; equalization and constant improvement of living conditions; support for regional development; economic development, trade and tourism; protection and improvement of the environment; cooperation in prevention and overcoming of natural disasters and catastrophes; cooperation in the field of humanitarian and social activities, in the field of education, sports and health; cultural exchange and care for cultural heritage.

It is substantiated that in contrast to the formation and functioning of Euroregional structures in the European Community, where the initiative to form such structural units mainly belongs to local communities, all Euroregions with the participation of administrative-territorial units of Ukraine were initiated by public administration structures. This has both positive aspects, because on the one hand, it shows that at the level of higher authorities there is an awareness of the need to participate in modern integration projects, to establish good neighborly relations between neighboring states. On the other hand, in the conditions of decentralization it is necessary to increase the independence of local authorities, active local policy in the field of interstate regional cooperation.

It is determined that today the Euroregion is the main tool for cooperation at the level of regions and territorial communities, acting as a cross-border regional association of border administrative territories in order to coordinate interstate regional cooperation.

Keywords. Public administration, regional administration, euroregion, interstate regional cooperation.

Постановка проблеми. Актуальність теми зумовлена необхідністю подальшого розвитку єврорегіонів як форми міждержавного регіонального співробітництва. Таке співробітництво має певні характеристики, які, узагальнюючи за науковими джерелами, можна представити наступним чином: організаційна структура єврорегіону виконує координаційні функції та не має владних повноважень, а також не може підмінювати органи влади, що діють на території кожного 3 його членів; у політичному сенсі єврорегіони не діють супроти національних інтересів держави, не $\epsilon$ наднаціональним утворенням, а сприяють розвитку світогосподарських зв'язків; необхідною умовою ефективного функціонування єврорегіонів $\epsilon$ наявність чітко визначених спільних інтересів їх членів; єврорегіони мають спеціальні управлінські структур, наприклад, Українська національна рада Карпатського єврорегіону та iї виконавча структура - Національне представництво України в Карпатському єврорегіоні та Асамблея українських прикордонних регіонів та євро регіонів.

Аналіз останніх публікацій та досліджень. Процес утворення та функціонування єврорегіональних структур в Свропейському співтоваристві розглянути в роботах науковців із різних галузей науки, таких як: В. Будкіна, 3. Варналія, М. Долішнього, Н. Мікули, Д. Норта та інших.

У сфері державного управління питання організаційно-правових механізмів, ролі держави в залученні інвестицій, формування 
єврорегіональних територій в Україні, прикордонної безпеки розглядалися у роботах Н. Діденко, I. Парубчака та інших. Проблематика більшості досліджень стосується конкретних прикордонних територій, практичної діяльності єврорегіонів, окремих механізмів або загальних тенденцій розвитку транскордонного співробітництва, що потребує уточнення та детального дослідження механізмів державного управління в сфері міждержавного регіонального співробітництва 3 країнами $С С$ в умовах посилення євроінтеграційних процесів та закінчення процесу децентралізації в Україні.

Мета статті. Здійснення аналізу особливостей розвитку єврорегіонів, об'єктно-предметної сфери державного управління міждержавним регіональним співробітництвом 3 метою інституційної адаптації до суспільно-політичних реалій України.

Виклад основного матеріалу. Державна підтримка розвитку єврорегіонів може здійснюватися шляхом: надання правової, інформаційної, методичної та організаційної допомоги місцевим органам виконавчої влади та органам місцевого самоврядування щодо участі в регіональному співробітництві та розвитку єврорегіонів; фінансування в установленому порядку відповідних заходів за рахунок коштів державного бюджету; участі у реалізації проектів, які підтримуються іноземними державами та міжнародними організаціями; сприяння в залученні міжнародної технічної допомоги та коштів спеціалізованих фондів міжнародних організацій [1].

Розвиток єврорегіонів на території України здійснюється відповідно до Законів України «Про транскордонне співробітництво», «Про місцеве самоврядування в Україні», «Про місцеві державні адміністрації», «Про зовнішньоекономічну діяльність», Угоди про асоціацію між Україною та СС, інших міжнародних договорів України.

Відзначимо, що на кордонах України 3 країнами $\mathrm{CC} \mathrm{створені}$ єврорегіони: «Буг» (Україна, Польща, Білорусь), «Карпатський єврорегіон» (Україна, Польща, Словаччина, Угорщина, Румунія), «Нижній Дунай» (Україна, Молдова, Румунія), «Верхній Прут» (Україна, Молдова, Румунія). Особливим єврорегіоном є регіон «Чорне море».

Підтримуємо думку знаних фахівців, що кожен з єврорегіонів має специфіку господарської діяльності, в тому числі позитивний та негативний досвід управлінської діяльності, що дозволяє на основі його аналізу визначити шляхи удосконалення діяльності єврорегіонів як найбільш ефективної на даний час форми взаємодії в сфері міждержавного регіонального співробітництва, зокрема за умов децентралізації [2].

Важливо, шо в практиці Карпатського єврорегіону (Україна, Польща, Словаччина, Угорщина, Румунія), площа якого складає 150 тис. кв. км, а населення - понад 16 млн. осіб. спостерігаємо приклад спільного історичного минулого, оскільки території, що входять в його складу, довгий час входили до складу імперії Габсбургів, що сприяло формуванню загальної економічної та транспортної інфраструктури взаємодоповнення ринків. 
Діяльність Карпатського єврорегіону як асоціації прикордонних регіонів і громад регулюється Угодою та Статутом. Керівним органом є Рада, до складу якої входять представники 5 національних делегацій (по 10 осіб від країни).

За роки існування Карпатського єрорегіону було реалізовано цілу низку важливих проектів в різних сферах: «Енергія Карпат» для підвищення якості публічних послуг у галузі енергозбереження в українській частині Карпатського Єврорегіону шляхом проведення аналізу наявних енергетичних ресурсів у гірських районах Львівщини, Івано-Франківщини та Закарпаття, а також охорона довкілля через використання власних енергоносіїв; реалізація Львівської обласної Програми «Питна вода» на 2012-2020 роки будівництво та реконструкція водозабірних споруд, зокрема у маловодних населених пунктах та 3 найбільшими відхиленнями якості води. Зараз також відбувається реалізація проекту «Здорові діти - щаслива нація» та «Карпатська мережа підтримки розвитку місцевих громад».

В рамках Карпатського єврорегіону створена система управлінських $\mathrm{i}$ консультаційних структур: багаторівнева структура управління українською частиною єврорегіону, яка складається 3 таких елементів: Українська національна рада Карпатського єврорегіону в складі голів обласних рад і державних адміністрацій Закарпатської, Івано-Франківської, Львівської та Чернівецької областей та АОМС «Сврорегіон Карпати - Україна», що діє на підставі положення; Постійний національний представник України в Карпатському єврорегіоні; виконавча структура - Національне представництво України в Карпатському єврорегіоні на базі Асоціації органів місцевого самоврядування «Єврорегіон Карпати - Україна» [3].

В цілому, Асоціація органів місцевого самоврядування «Єврорегіон Карпати - Україна» створена 3 метою сприяння розвитку територій Львівської, Закарпатської, Івано-Франківської та Чернівецької областей, що належать до Карпатського єврорегіону, координації та систематизації діяльності місцевих громад цього об'єднання в сфері регіональної співпраці, зокрема щодо розвитку підприємництва й туризму, в екологічній сфері, в тому числі енергоощадження та використання альтернативних джерел енергії, розвитку транспортної й прикордонної інфраструктури та міжлюдській співпраці в межах зазначеного міжрегіонального об'єднання.Досить ефективно працює Карпатський ресурсний центр громад, у рамках якого працівники асоціації на постійній основі надають консультації представникам місцевих громад Карпатського Єврорегіону 3 питань стратегічного планування місцевого розвитку, проектного менеджменту та залучення ресурсів на місцевому рівні, діалогу з владою.

Ефективно функціонують Асоціація університетів Карпатського Сврорегіону, яка забезпечує організацію літніх шкіл, спортивних змагань (традиційного фольклорного i спортивного фестивалю), спортивних фестивалів для людей з фізичними вадами та Асоціація карпатських торговопромислових палат, в рамках якої Карпатський єврорегіон здійснює 
співробітництво 3 міжнародними структурами, зокрема 3 Комітетом економіки Свропи при ООН, єврорегіоном «Maas-Rijn».

Відзначимо, що інституційне удосконалення діяльності Карпатського єврорегіону передбачає посилення економічної складової співпраці, підвищення рівня фінансування транскордонних програм, які реалізуються в єврорегіоні, з боку України; вироблення та втілення єдиної операційної програми ЄС для регіону Карпат для розгляду його як спільної європейської спадщини - цілісної екологічної, економічної та гуманітарної системи (як підетап реалізації проекту «Карпатський Горизонт- 2020»); збільшення прямих іноземних інвестицій з боку країн-членів СС, зокрема, за рахунок виконання проекту East Invest II; започаткування та узгодження транскордонних кластерних ініціатив та розвитку транскордонних кластерів (насамперед, втілення пропозицій щодо транскордонного туристичного кластеру [4].

Звернемо увагу на те, що серед інституційних прорахунків, що ускладнюють процес фінансування проектів регіонального розвитку в межах Карпатського Єврорегіону, особливого значення набувають такі: відмінність виконавчих структур кожної 3 національних сторін, а також відсутність чіткої нормативно-правової бази функціонування єврорегіону, що суттєво обмежує управлінські можливості органів публічної влади.

Відзначимо, що відповідно до українського законодавства функціонування суб'єктів міжнародного співробітництва регулюється нормативно-правовими актами, що можуть ініціюватися лише центральними органами влади. Натомість до переліку повноважень обласних рад України не входить розроблення та реалізація програм міжнародного співробітництва на рівні відповідних областей. Згідно 3 офіційними звітами національних представництв Карпатського Єврорегіону, більшість реалізованих проектів $\epsilon$ двосторонніми. Часто такі проекти втілено саме завдяки інструментам міждержавного міжрегіонального співробітництва, зокрема в рамках Європейського Інструменту Сусідства та Партнерства. Водночас українська сторона не визначає пріоритетних напрямків проектів, що мають бути реалізовані на ії території КЄ коштом зазначених вище програм. Українські представники Карпатського Єврорегіону не беруть участь у робочих органах із розроблення та управління Програмами транскордонного співробітництва, a також у міжурядових радах і комісіях 3 питань транскордонного та міжрегіонального співробітництва, діяльність яких безпосередньо стосується територій єврорегіону.

На заваді успішній роботі української сторони у межах Карпатського Єврорегіону стають й обмежені інституційні можливості участі центральних органів влади у процесі узгодження положень регіональних стратегій розвитку з державними програмами транскордонного співробітництва та розвитку європейської інтеграції.

Функціонування Єврорегіону «Буг» здійснюється керівними органами Радою єврорегіону (до складу входять по 10 представників від кожної зі сторін), Президією Ради євро регіону (складається з трьох членів (по одному 
від кожної сторони), які призначаються Радою), Секретаріатом (створюється Радою, з однаковою кількістю представників від кожної сторони. Кожна сторона має відділення Секретаріату, до складу якого входять члени Секретаріату однієї країни, працюють вони без взаємного підпорядкування.) та ревізійною комісією.

Для вирішення спільних завдань Сврорегіону «Буг» створено 8 робочих груп: група територіального планування, комунікації, транспорту і зв'язку; група охорони й поліпшення стану навколишнього середовища; група поширення інформації та створення баз даних; група співробітництва між установами й різними галузями господарства; група освіти, охорони здоров'я, культури, спорту, туризму і молоді; група контактів між органами місцевого самоврядування та населенням; група безпеки, взаємодії правоохоронних органів і ліквідації загрозливих станів; група розвитку спільного кордону та прикордонної інфраструктури.

Відзначмо, що єврорегіон «Буг» $є$ членом Асоціації європейських прикордонних регіонів, яка має значний вплив на розвиток відносин між прикордонними територіями Свропи, і в прийнятті рішень якої значну роль відіграють транс- і прикордонні об'єднання європейського континенту.

Учасниками Сврорегіону «Буг» здійснено низку вагомих проектів $\mathrm{i}$ програм, спрямованих на розвиток бізнесу, гуманітарної сфери, розбудову кордону та створення прикордонної інфраструктури, охорону навколишнього середовища, розвиток місцевого самоврядування та ін.

Прикладом вирішення управлінських проблем $\epsilon$ реалізація в Єврорегіоні «Буг» проектів, спрямованих на створення українсько-польської транскордонної агенції регіонального розвитку, розробку українськопольської стратегії транскордонної співпраці, підтримку й розвиток українсько-польської співпраці в галузі надання консультаційних та освітніх послуг для малих і середніх підприємств.

Для формування позитивного іміджу прикордонних територій, вважаємо, важливими були такі проекти як: «Створення українськопольської віртуальної біржі інноваційних проектів та пропозицій», «Розвиток екологічного туризму та формування позитивного туристичного іміджу прикордонного регіону», «Поліпшення інвестиційного клімату в прикордонних регіонах».

Функціонування Сврорегіону «Нижній Дунай» здійснюється через Раду Єврорегіону - найвищий орган управління, який ухвалює всі рішення (9 осіб - по 3 від кожної сторони); комісії зі сфер діяльності (9); координаційний центр. Відповідно до діючого статуту членами Ради єврорегіону від Одеської області за посадами є: голова обласної державної адміністрації; голова обласної ради; голова Ренійської районної ради. Адміністративним органом єврорегіону $є$ координаційний центр, до якого входять представники всіх адміністративно- територіальних одиниць - членів єврорегіону, які призначаються Радою строком на два роки, а також 2 координатори, які забезпечують діяльність голови єврорегіону, та по 1 координатору, що забезпечують діяльність віце-голів. Комісії зі сфер діяльності: регіонального 
розвитку i транскордонного співробітництва; 3 розвитку та просування транскордонного туризму; 3 навколишнього середовища та надзвичайних ситуацій; з місцевого економічного розвитку та стратегічного планування; iз транспорту, комунікацій та енергетики; з охорони здоров'я та соціальної сфери; з освіти, науки та спортивної діяльності; з культурної діяльності та міжетнічних відносин; зі сприяння діяльності щодо безпеки людини та боротьби зі злочинністю. Єврорегіон є членом Асоціації європейських прикордонних регіонів.

Єврорегіон «Верхній Прут», який представляє регіональну співпрацю між Україною та Румунією, зосереджений на таких напрямах як: природокористування та навколишнє середовище, інвестиційний проект iз модернізації технологічної бази деревообробної промисловості Сучавського повіту, розвиток інфраструктури Сучавського аеропорту, будівництво вантажного терміналу на КПП «Сірет», створення Центру економіки та підприємництва «Буковина», заснування навколо м. Сірет у районі українсько- румунського кордону режиму вільної економічної зони.

Єврорегіон «Верхній Прут» специфічний тим, що у його складі сформований екологічний єврорегіон, тобто як форма співробітництва в межах єврорегіону (його складова частина) між органами державного та місцевого управління, спеціалізованими організаціями у сфері охорони довкілля, екологічної безпеки, моніторингу, цивільного захисту населення, санітарно- епідеміологічного нагляду, а також між суб'єктами господарської діяльності межуючих країн, спрямована на покращання техногенноекологічної безпеки у басейнах річок та на певних територіях 3 метою забезпечення сталого (самовідтворюючого) соціально-економічного розвитку цих територій.

Керівництво Єврорегіоном здійснюється Радою єврорегіону, до складу якого входять керівники адміністративно-територіальних одиниць-членів єврорегіону і на чолі якої стоїть Виконавчий Голова Ради Сврорегіону. Для координації діяльності між засіданнями ради створений Секретаріат Ради єврорегіону, який утворюється на базі органу влади, керівник якого виконує функції Виконавчого голови, яка головує. До складу секретаріату входять також по одному представнику від кожної адміністративно-територіальної одниці єврорегіону.

Вагоме місце в співпраці за різними напрямками займають робочі Комісії Сврорегіону: з питань економіки, інфраструктури і туризму; з питань екологічної безпеки, охорони довкілля, сталого (самовідтворюючого) розвитку регіону та діяльності єкоєврорегіону; 3 питань науки, освіти, культури, охорони здоров'я, спорту та молоді; 3 питань розвитку міжрегіональних і міжнаціональних зв'язків, місцевого самоврядування та засобів масової інформації [5].

Статут також передбачає, що для виконання конкретних проектів, програм чи окремих завдань за рішеннями Ради Єврорегіону чи відповідних Робочих Комісій створюються Експертні (робочі) групи, діяльність котрих є 
постійною доти, поки експертну (робочу) групу не буде розпущено після завершення конкретної роботи (програми, проекту).

Проблемами Єврорегіону стали недостатній рівень активності економічного співробітництва, яке б збільшувало надходження в державні та місцеві бюджети, складні системи митної процедури, відсутність системи взаємовизнання сертифікатів, необхідність оформлення в різних структурах значної кількості дозвільних документів.

Важливо, що в рамках Програми сусідства PHARE CBC «Румунія Україна» було впроваджено 147 проектів 80 аплікантами за підтримки 95 партнерів з України. Найбільша кількість проектів була реалізована у Сучавському повіті (50 грантів). Серед транскордонних проектів, які стали найбільш вдалими: проекти гуманітарного напрямку - 4 проекти Чернівецького регіонального центру перепідготовки та підвищення кваліфікації працівників органів державної влади, органів місцевого самоврядування, державних підприємств, установ та організацій спільно зі своїми румунськими партнерами-аплікантами; 2 проекти Чернівецького обласного громадського об’єднання «Буковинські перспективи»; проект «Популяризація спільної культурної спадщини в транскордонному регіоні Чернівці - Сучава», який реалізовувався Чернівецькою міською радою, міською радою Кимпулунг-Молдовенеск, муніципалітетом Сучави та іншими партнерами; проекти у сфері економіки та туризму - «Створення інтегрального туристичного продукту для розвитку культурного туризму на Буковині», «Транскордонне співробітництво 3 інвестиційного розвитку сільських регіонів», «Буковинський інноваційний центр» та ін [6].

Сврорегіон «Чорне море» став ще одним єврорегіоном, у якому задіяно територію Одеської області. Після утворення в ще лютому 2006 р. у Венеції першого єврорегіону нового зразка (з акцентом на співробітництві в регіоні напівзакритого моря та поєднанням регіонів держав-членів і нечленів Європейського Союзу) під назвою «Адріатика» в Конгресі місцевої та регіональної влади Ради Європи виникла ідея створення таких самих єврорегіонів навколо Балтійського та Чорного морів. 30 березня 2006 р. в м. Констанці за ініціативи Румунії відбулася перша міжнародна конференція 3 питань міжрегіонального співробітництва в басейні Чорного моря. У своїй Заключній декларації всі учасники конференції (причорноморські країни, крім Росії, що відмовилася від участі в заході) звернулися до Конгресу місцевої й регіональної влади з проханням сприяти створенню до кінця 2007 p. єврорегіону «Чорне море» і закликали Комітет міністрів Ради Європи підтримати цю ініціативу.

Правовою базою співробітництва $є$ Статут Сврорегіону «Чорне море», розроблений відповідно до Регламенту № 1082 щодо Європейських угруповань територіального співробітництва (СУТС)137. Метою діяльності єврорегіону є захист спільних інтересів членів і підготовка спільної стратегії розвитку; обмін досвідом і ноу-хау; підготовка спільних програм і стратегій розвитку, а також реалізація дій, спрямованих на їх імплементацію; розвиток 
соціальної й економічної діяльності, повага до навколишнього середовища. Штаб-квартира єврорегіону знаходиться у м. Констанца (Румунія) [7].

Висновки. Узагальнюючи аналіз діяльності діючих єврорегіонів за участі України та країн ЄС, можна виділити такі перешкоди для ефективного функціонування української сторони: відсутність системного та перспективного підходу до організації єврорегіональної співпраці та єдності у розумінні змісту та характеру транскордонного співробітництва на рівні єврорегіонів; необхідність удосконалення фінансового забезпечення i виділення відповідних коштів в місцевому, регіональному, центральному бюджетах; низький рівень підготовки кадрів в регіональних та місцевих органах управління для організації міждержавного регіонального співробітництва; недостатньо опрацьовані та впроваджені відповідні організаційні методи, інструменти, принципи, процедури, структури i правове регулювання співпраці, що суттєво обмежує ефективну участі української сторони у єврорегіональній співпраці; недостатність позитивних прикладів практичної співпраці у рамках єврорегіонів; необхідність організації ефективної презентації інтересів місцевих органів самоврядування на форумах європейських інституцій та організацій, які займаються транскордонною співпрацею.

Основними напрямами удосконалення роботи єврорегіонів пропонуємо наступні: розвиток єврорегіонів як найбільш ефективної форми міждержавного регіонального співробітництва 3 визначенням їх ролі та статусу в регіональній політиці держави на законодавчому рівні; збільшення фінансування, в тому числі в контексті реалізації Державної програми розвитку транскордонного співробітництва на 2016-2020 роки; виділення в межах кожного регіону територіальних стратегічних проектів, орієнтованих на вирішення певного напряму транскордонних проблем; розробка стратегії розвитку кожного єврорегіону з урахуванням їх специфіки та пріоритетних напрямах відповідних цільових проектів; удосконалення управлінських структур єврорегіонів шляхом раціонального вибору управлінських органів, забезпечення відповідними фахівцями, спрощенням механізму прийняття управлінських рішень; активне залучення до розвитку єврорегіонів підприємницьких структур, освітніх і наукових закладів, медичних установ, культурно-мистецьких центрів, молодіжних осередків тощо; впровадження в рамках єврорегіонів інноваційних форм співробітництва; підтримка участі неурядових організацій в транскордонній співпраці, забезпечення їх належного представництва у всіх робочих органах єврорегіонів.

\section{Література:}

1. Воротін В. Є. Модернізація сфери освіти та науки як об'єкта державного управління: конкурентні переваги для України. Наукові записки Інституту законодавства Верховноі Ради України. 2017. № 6. С.153-160.

2. Норт Д. Институты, институциональные изменения и функционирование экономики. М.: Начала, 1997. 180 с. 
3. Інституційні важелі розвитку об’єднаних територіальних громад в умовах децентралізації управління: аналітична записка / Національний інститут стратегічних досліджень. URL: http: // www.niss. gov.ua/articles/2668/ (дата звернення: 01.08.2020).

4. Vorotin V. Ye., Romanenko Ye. A., Shchokin R. G., Pivovarov K. V. Improving the organizational and legal mechanism of state economic management: the european experience for Ukraine. Financial and credit activity: problems of theory and practice. 2018. № 3 (26), 368376.

5. Про схвалення Концепції реформування місцевого самоврядування та територіальної організації влади в Україні: розпорядження Кабінету Міністрів України від 1 квітня 2014 р. № 333-p // База даних «Законодавство України» / BP України. URL: https://zakon.rada.gov.ua/laws/show/333-2014-\%D1\%80\#Text (дата звернення 20.07.2020).

6. Угода про асоціацію між Україною та Європейським Союзом // База даних «Законодавство України» / ВР України. URL: https://zakon.rada.gov.ua/laws/show/984_011 (дата звернення: 20.07.2020).

7. Порядок денний асоціації між Україною та ЄС для підготовки та сприяння імплементації Угоди про асоціацію // База даних «Законодавство України» / ВР України. URL: https://zakon.rada.gov.ua/laws/card/994_990 (дата зверення: 20.07.2020).

\section{References:}

1. Vorotin, V. Ye. (2017). Modernizatsiia sfery osvity ta nauky yak oblekta derzhavnoho upravlinnia: konkurentni perevahy dlia Ukrainy. Naukovi zapysky Instytutu zakonodavstva Verkhovnoi Rady Ukrainy, 6, 153-160 [in krainian].

2. North D. Institutions, institutional changes and the functioning of the economy / Douglas North [Per. With English]. M.: Started, 1997. 180 p.

3. "Institutional levers of development of the combined territorial communities in the conditions of decentralization of management". Analytical note. URL:

http://www.niss.gov.ua/articles/

4. Vorotin, V. Ye., Romanenko, Ye. A., Shchokin, R. G., Pivovarov, K. V. (2018). Improving the organizational and legal mechanism of state economic management: the european experience for Ukraine. Financial and credit activity: problems of theory and practice, 3 (26), 368-376 [in Ukrainian].

5. Concept of the reform of local selfgovernment and territorial organization of power in Ukraine (approved by the Cabinet of Ministers of Ukraine from April 1, 2014, № 333-p). URL: https://zakon.rada.gov.ua/laws/show/333-2014-\%D1\%80\#Text

6 Association Agreement between Ukraine and the European Union [Electronic resource]. — URL: https://zakon.rada.gov.ua/laws/show/984_011

7. Agenda of the Association between Ukraine and the EU for the preparation and promotion of the implementation of the Association Agreement [Electronic resource]. URL: https://zakon.rada.gov.ua/laws/card/994_990 